\section{Optimasi Pembentukan Bioflok Dari Chaetoceros sp., Thalassiosira sp. dan Bakteri Probiotik Melalui Variasi Salinitas Secara In Vitro}

\author{
Suciati Nurdin
}

\begin{abstract}
Abstrak. Bioflok merupakan suspensi yang terdapat di dalam air yang terdiri dari mikroalga, dan bakteri yang berpotensi dikembangkan dalam bidang akuakultur yaitu sebagai pakan alami karena kandungan protein yang tinggi juga sebagai alternative pemecahan masalah limbah budidaya. Penelitian ini bertujuan untuk mengetahui bagaimana optimasi pembentukan bioflok dari Chaetoceros sp., Thalassiosira sp. dan bakteri probiotik melaui tingkat salinitas optimum yang digunakan pada medium walne. Penelitian ini dilakukan di Laboratorium Biologi Universitas Negeri Makassar. Penelitian ini merupakan penelitian eksperimen menggunakan Rancangan Acak Lengkap (RAL) yang terdiri atas 5 perlakuan dan 3 ulangan, yaitu perlakuan dengan salinitas 30 ppt (S1), perlakuan dengan salinitas 25 ppt (S2), perlakuan dengan salinitas 20 ppt (S3), perlakuan dengan salinitas 15 ppt (S4), dan perlakuan dengan salinitas 5 ppt (S5) pada medium walne dengan menggunakan kombinasi inokulan Chaetoceros sp., Thalassiosira sp. dan bakteri probiotik. Parameter yang diamati yaitu biomassa (berat kering) flok, volume flok, aktivitas flok, suhu, pH, intensitas cahaya, dan laju aerasi. Data dianalisis dengan menggunakan Analysis of Variance (ANOVA) dan dilanjutkan dengan uji Duncan $(\alpha$ 0,05). Hasil penelitian menunjukkan perlakuan S2 dengan salinitas 25 ppt merupakan salinitas optimum untuk pembentukan bioflok yang ditunjukkan dengan biomassa flok tertinggi, volume flok tertinggi, dan aktivitas flok tertinggi yaitu dengan indikator biomassa flok 0.00546 $\mathrm{g} / \mathrm{ml}$, volume flok sebesar $0.0071 \mathrm{ml}$, dan aktivitas flok sebesar $77.0262 \%$. Kata kunci: Bioflok, Salinitas, Chaetoceros sp., Thalassiosira sp., Bakteri Probiotik.
\end{abstract}

\section{Pendahuluan}

Udang merupakan salah satu komoditas ekspor sub sektor perikanan yang memiliki nilai ekonomi tinggi. Pemerintah melalui Kementerian Kelautan dan Perikanan (KKP) menargetkan kenaikan terhadap produksi udang sebesar $74,75 \%$ di tahun 2010-2014, yaitu dari 400.000-ton menjadi 699.000 ton. Dalam pencapaian target tersebut, peningkatan produksi udang akan diarahkan pada udang windu (Penaeus monodon) dan udang putih (Litopenaeus vannamei) (Pantjara, 2008).

Salah satu sumberdaya hayati perairan bernilai ekonomis penting dan telah dibudidayakan secara komersial adalah udang putih (Litopenaeus vannamei). Udang putih beberapa tahun terakhir mengalami perkembangan cukup pesat dan diharapkan dapat menggantikan sementara udang windu dan memberikan andil terhadap perolehan devisa negara setelah menurunnya produksi udang windu. Namun kendala dalam usaha pembesaran udang putih seringkali terbentur pada kurang terkontrolnya aspek-aspek

\section{BIONATURE}

\section{ISSN 1411 - 4720}

Abstract. Biofloc is a suspension contained in water consisting of microalgae, and bacteria that are potentially developed in the field of aquaculture that is as a natural food because of high protein content as well as alternative solutions to the problem of cultivation waste. This study aims to find out how the optimization of biofloc formation from Chaetoceros sp.,

Thalassiosira sp. and probiotic bacteria through the optimum salinity level used on the walne medium. This research was

conducted at the Laboratory of Biology, State University of Makassar. This study was an experimental study using a completely randomized design (CRD) consisting of 5 treatments and 3 replications, namely with salinity 30 ppt (S1), treatment with salinity $25 \mathrm{ppt}$ (S2), treatment with salinity $20 \mathrm{ppt}$

(S3), treatment with salinity 15 ppt (S4),

and 5 ppt (S5) salinity treatment on walne medium with using a combination of inoculants Chaetoceros sp., Thalassiosira sp. and probiotic bacteria. Parameters

observed were biomass (dry weight) floc,

floc volume, floc activity, temperature, $\mathrm{pH}$, light intensity, and aeration rate. Data were analyzed using Analysis of Variance

(ANOVA) followed by Duncan test ( $\alpha$ 0.05).

The result of the research shows that the salinity of 25 ppt is the optimum salinity for biofloc formation which is indicated by the highest floc biomass, the highest floc

volume, and the highest floc activity with floc biomass indicator $0.00546 \mathrm{~g} / \mathrm{ml}$, floc volume $0.0071 \mathrm{ml}$, and floc activity $77.0262 \%$

Keywords: Biofloc, Salinity, Chaetoceros sp., Thalassiosira sp., Probiotic Bacteria.

Suciati Nurdin

Universitas Negeri Makassar Indonesia 
teknis budidaya salah satunya adalah aspek pemanfaatan pakan (Haliman dan Adijaya, 2005). Penurunan kualitas lingkungan disebabkan limbah organik dari sisa pakan dan kotoran, limbah umumnya didominasi oleh senyawa nitrogen anorganik yang beracun. Hal tersebut disinyalir lebih banyak diproduksi oleh pakan buatan (Stickney, 2005). Pengaruh yang lebih signifikan terhadap permasalahaan tersebut disebabkan karna kurangnya peneyediaan pakan alami. Penyedian pakan alami yang berkualitas dan mencukupi sangat penting untuk pemeliharaan larva berbagai biota perairan seperti ikan dan udang (Erniati dan Hariana, 2012).

Berdasarkan hal tersebut, untuk meningkatkan produktivitas akuakultur melalui peningkatan kelangsungan hidup, efisiensi pakan dan pertumbuhan ikan atau udang serta penurunan limbah kegiatan akuakultur (pengembangan kualitas air) dapat diaplikasikan melalui teknologi bioflok (Bioflocs Technology) (Avnimelech, 2007). Bioflok merupakan suspensi yang terdapat di dalam air yang terdiri dari mikroalga, dan bakteri (Hargreaves, 2006). Salah satu fitoplankton yang berpotensi dikembangkan dalam bidang akuakultur yang biasa digunakan sebagai pakan udang putih yaitu Thalassiosira sp., dan Chaetoceros sp. Spesies tersebut sudah dapat dikultur secara besar-besaran sebagai pakan dan memberikan nutrisi berkualitas secara optimum untuk organisme seperti larva udang sesuai pada stadia perkembangannya (Triswanto, 2011). Selain mikroalga, Penggunaan probiotik diharapkan dapat membantu perbaikan kualitas air tambak, sedangkan konsep bioflok diharapkan mampu merangsang tumbuhnya bakteri probiotik dalam bentuk flocs sehingga mampu memperbaiki kualitas air serta mampu mengurangi ketergantungan udang terhadap pakan buatan (Febrianti, 2010).

Demi mengembangkan dan menjaga keberadaan mikroorganisme yang menguntungkan dalam kolam merupakan kunci sukses bioflok. Mikroorganisme baik fitoplankton maupun bakteri menguntungkan tersebut harus dijaga dominasinya agar dapat membentuk gumpalan flok yang banyak. Berdasarkan hasil penelitian Widianingsih dkk (2008), Media Walne merupakan media kultur yang baik bagi fitoplankton yang memiliki kandungan nutrient yang baik. Oleh karena itu, perlu dilakukan variasi pada media kultur walne sebagai media pertumbuhan fitoplankton yang diikuti oleh penambahan probiotik yang mengandung bakteribakteri menguntungkan yang juga menunjang dalam pembentukan bioflok.

Adanya masalah yang timbul akibat intensifikasi budidaya udang adalah penurunan kualitas air dan efisiensi pakan maka perlu dikembangkan suatu system budidaya efektif berbasis bioflok yang menggunakan komunitas mikroorganisme (fitoplankton dan bakteri). mikroorganisme pembentuk flok tersebut harus dijaga dominansinya dengan menciptakan kondisi lingkungan optimum. Faktor lingkungan selain suhu, $\mathrm{pH}$, intensitas cahaya, maupun laju aerasi dibutuhkan pula salinitas dalam upaya pembentukan bioflok sehingga perlu adanya penelitian dalam mengkaji dan mencari salinitas yang optimum bagi pertumbuhan mikroorganisme dalam pembentukan bioflok.

\section{Metode Penelitian}

Penelitian ini merupakan penelitian eksperimen yaitu untuk mengetahui pembentukan optimum bioflok dari Chaetoceros sp., Thalassiosira sp. dan bakteri probiotik melalui variasi salinitas secara in vitro. yang dilaksanakan pada bulan April 2017 hingga Oktober 2017 di Laboratorium Biologi Universitas Negeri Makassar.

\section{Alat dan Bahan}

Alat yang digunakan pada penelitian ini yaitu Erlenmeyer $(100 \mathrm{ml}, 250 \mathrm{ml}, 500 \mathrm{ml}$ dan $1000 \mathrm{ml}$ ), gelas kimia (500 ml dan $1000 \mathrm{ml})$, gelas ukur $(10 \mathrm{ml}, 100 \mathrm{ml}, 250 \mathrm{ml}$, dan $1000 \mathrm{ml})$, tabung reaksi, tabung falcon, spoit steril $(1 \mathrm{ml}, 5 \mathrm{ml})$, aerator, mikropipet dan tip, mikrotube, batang pengaduk, botol selai steril, botol biakan, botol pengencer, Laminar Air Flow (LAF), autoclave, oven, neraca analitik, spektrofotometer, cuvet, bunsen, hot plate, kamera, lampu TL 40 
Optimasi Pembentukan Bioflok Dari Chaetoceros sp., Thalassiosira sp. dan Bakteri Probiotik Melalui Variasi Salinitas Secara In Vitro

ISSN $1411-4720$

(hlm. 140-151)

watt, selang aerasi, batu gelembung, cabangan selang, corong, mikroskop elektrik merk Leica CM-E, objek glass, deck glass, termometer air, pipet tetes, $\mathrm{pH}$ meter, refraktometer dan Lux meter.

Bahan yang digunakan yaitu air laut bersalinitas 33 ppt (diperoleh dari Pantai Puntondo yang terletak di Dusun Puntondo, Desa Laikang, Kecamatan Mangara'Bombang, Kabupaten Takalar, Sulawesi Selatan), alkohol 70\%, spiritus, aquadest, Medium NB (Nutrient Broth), $\mathrm{FeCl}_{3}$, $\mathrm{MnCl}_{2} .4 \mathrm{H}_{2} \mathrm{O}, \mathrm{H}_{3} \mathrm{BO}_{3}$, EDTA, $\mathrm{NaH}_{2} \mathrm{PO}_{4} \cdot 2 \mathrm{H}_{2} \mathrm{O}, \mathrm{NaNO}_{3}, \mathrm{ZnCl}_{2}, \mathrm{CoCl}_{2} \cdot 6 \mathrm{H}_{2} \mathrm{O},\left(\left(\mathrm{NH}_{4}\right)_{6} \mathrm{MO}_{7} \mathrm{O}_{24} \cdot 4 \mathrm{H}_{2} \mathrm{O}\right)$, $\mathrm{CuSO}_{4} .5 \mathrm{H}_{2} \mathrm{O}$, $\mathrm{HCl}$ pekat, $\mathrm{Na}_{2} \mathrm{SiO}_{3} .5 \mathrm{H}_{2} \mathrm{O}, \mathrm{NaOH}$, Vitamin $\mathrm{B} 1$ dan $\mathrm{B} 12, \mathrm{CaCl}_{2}$, Caulin clay, bibit Chaetoceros sp., Thalassiosira sp. (diperoleh dari BBAP Takalar), bakteri probiotik (diproduksi oleh PT.Marindolab Pratama Makassar), kapas, alumunium foil, label, tissue, plastik, wrap, kertas saring, dan kertas whatman No.1

\section{a. Persiapan Alat dan Bahan}

\section{Prosedur Kerja}

1. Penyiapan Air laut

Air laut yang digunakan untuk mengkultur bibit Chaetoceros sp., dan Thalassiosira sp. disterilisasi menggunakan autoclave pada suhu $115^{\circ} \mathrm{C}$ selama 30 menit (Trikuti et.al., 2016). kemudian disaring dan diencerkan dengan berbagai tingkat kadar garam (salinitas) yaitu 30 ppt, 25 ppt, 20 ppt, 15 ppt, dan 5 ppt. Pengenceran dilakukan dengan menggunakan rumus:

Keterangan:

$$
\text { V1.M1 = V2.M2 }
$$

V1: Volume awal sebelum pengenceran

M1: Konsentrasi garam (salinitas) sebelum pengenceran

V2: Volume akhir setelah pengenceran

M2: Konsentrasi garam (salinitas) akhir setelah pengenceran.

Pengukuran salinitas dilakukan dengan mengambil 1-2 tetes sampel dengan spoit kemudian diukur menggunakan Refraktometer.

\section{Sterilisasi Alat dan Medium}

Peralatan yang akan digunakan dicuci bersih kemudian dibilas dengan air tawar. Semua peralatan kaca tahan panas dan medium yang akan digunakan dalam penelitian ini harus dalam keadaan steril untuk meminimalkan faktor kontaminasi yang disterilkan dengan menggunakan autoclave dengan suhu $121^{\circ} \mathrm{C}$ selama 15 menit. Peralatan ini harus ditutup dengan kapas dan dibungkus dengan aluminium foil. Peralatan yang tidak tahan panas disterilisasi menggunakan alkohol 70\%.

3. Pembuatan Medium Walne

Medium yang digunakan untuk mengkultur Chaetoceros sp., dan Thalassiosira sp. dalam penelitian ini adalah medium Walne (Cotteau, 1998). Medium tersebut dipilih karena berdasarkan hasil penelitian Widianingsih et.al., (2008), media Walne merupakan media kultur yang terdiri dari komposisi yang baik untuk mendukung pertumbuhan Chaetoceros sp., dan Thalassiosira sp. Beberapa larutan stok medium yaitu larutan A, larutan B, larutan C, larutan D dan larutan E.

\section{b. Persiapan Inokulum Chaetoceros sp., dan Thalassiosira sp. pada medium Walne}

Fitoplankton Chaetoceros sp., dan Thalassiosira sp. yang digunakan pada penelitian ini adalah kultur cair yang diperoleh dari Laboratorium Pakan Alami, Balai Budidaya Air Payau (BBAP) Takalar. Bibit murni Chaetoceros sp., dan Thalassiosira sp. Masing-masing diinokulasikan pada medium cair untuk dikultur. 
Bibit Chaetoceros sp., dan Thalassiosira sp. masing-masing dikultivasi ke medium Walne untuk mengadaptasikannya dengan medium Walne yang akan digunakan pada penelitian ini. Jumlah inokulum yang digunakan untuk kultivasi adalah 10\% (Kurniawati, 2006). Chaetoceros sp., dan Thalassiosira sp. masing-masing di kultur dengan menggunakan botol kultur steril berdiameter $7 \mathrm{~cm}$ dengan tinggi $24 \mathrm{~cm}$ dan sebanyak $800 \mathrm{ml}$ medium Walne. Selanjutnya diaerasi atau diinkubasi pada suhu $25-24^{\circ} \mathrm{C}$ selama 6-7 hari. Hasil kultivasi selanjutnya akan digunakan sebagai inokulum perlakuan.

\section{c. Optimasi Pertumbuhan Chaetoceros sp., dan Thalassiosira sp.}

Optimasi pertumbuhan Chaetoceros sp., dan Thalassiosira sp. Diekspresikan dengan cara dikombinasikan secara bersama dan dilakukan dengan mengambil masing-masing $10 \%$ hasil kultivasi persiapan inokulum dan memasukkannya ke dalam $800 \mathrm{ml}$ medium yang telah divariasikan dengan salinitas yang diinginkan. Sehingga diperoleh rancangan percobaan dalam penelitian ini yaitu 5 perlakuan dengan masing-masing 3 kali ulangan yaitu:

Medium 1 (S1) ; medium walne salinitas $30 \mathrm{ppt}$

Medium 2 (S2) ; medium walne salinitas $25 \mathrm{ppt}$

Medium 3 (S3) ; medium walne salinitas $20 \mathrm{ppt}$

Medium 4 (S4) ; medium walne salinitas $15 \mathrm{ppt}$

Medium 5 (S5); medium walne salinitas 5 ppt

\section{d. Pemberian Probiotik}

Probiotik yang digunakan dalam penelitian ini adalah probiotik cair (diproduksi oleh PT. Marindolab Pratama Makassar), yang terdiri dari beberapa komponen bakteri seperti Rhodobacter sp. dan Rhodococcus sp. Sebelum probiotik diinokulasikan ke dalam botol kultur yang berisi fiitoplaknton, terlebih dahulu probiotik tersebut diaktifkan menggunakan medium NB dengan cara memasukkan $5 \mathrm{ml}$ probiotik kedalam $500 \mathrm{ml}$ medium NB, dan dishaker selama 24 jam dengan laju $250 \mathrm{rpm}$. Probiotik yang telah diaktifkan kemudian diambil sebanyak $2,5 \mathrm{ml}$ dan diinokulasikan kedalam botol kultur yang didalamnya terdapat fitoplankton berupa Chaetoceros sp., dan Thalassiosira sp.

\section{e. Parameter Pengamatan}

Pengukuran biomasa flok diekspresikan dalam berat keringnya, yang dilakukan dengan mengambil $20 \mathrm{ml}$ sampel pada tiap wadah yang telah diaduk/dihomogenkan sebelumya kemudian disaring dikertas whatman no 1 yang telah ditimbang sebelumnya sebagai berat bersih kertas $\left(\mathrm{V}_{0}\right)$. Kemudian dioven pada suhu $105^{\circ} \mathrm{C}$ selama 1 jam dan ditimbang pada neraca analitik (Vt). Kemudian diulangi hingga memperoleh berat yang konstan. Biomassa akhir diketahui dengan menghitung selisih antara $\mathrm{Vt}$ dan $\mathrm{V}_{0}$.

Pengukuran volume flok diukur dengan mengambil $10 \mathrm{ml}$ sampel kemudian di masukkan kedalam tabung falcon dan didiamkan selama 20 sampai 30 menit hingga terbentuk dua lapisan. Lapisan bagian atas berupa cairan sedangkan lapisan bagian bawah berupa endapan. Pengukuran volume endapan yang ada pada laisan bawah dilakukan dengan menggunakan spoit. Hasil pengukuran endapan itulah yang dimaksud sebagai volume flok. Suprapto dan Samtafsir (2013), menyatakan bahwa volume flok merupakan salah satu cara untuk melihat kelimpahan organisme pembentuk bioflok.

Pengukuran Aktivitas flok, diukur dengan menggunakan spektrofotometer. Dengan panjang gelombang $600 \mathrm{~nm}$. Sebelum diukur terlebih dahulu mengambil masing-masing sebanyak $1 \mathrm{ml}$ dan memasukkan ke dalam mikrotube berukuran 2 mll lalu di centrifuge dengan kecepatan $10000 \mathrm{rpm}$ selama 5 menit hingga terbentuk 2 lapisan. Lapisan bagian supernatan larutan bioflokulan demasukkan kedalam tabung reaksi sebanyak 0,1 $\mathrm{ml}$ dan di tambahkan dengan larutan Caulin clay yang sebelumnya telah dilarutkan dengan aquadest sebanyak $5 \mathrm{gr} / \mathrm{L}$ dengan $\mathrm{pH}$ 7. Setelah itu ditambahkan $0,25 \mathrm{ml} \mathrm{CaCl}_{2}$, kalsium klorida adalah bahan flokulan yang sudah dikenal dan termasuk dalam jenis polimer kation (Triphaty dan De Ranjan 2006). kemudian dihomogenkan dan diukur aktivitas biofloknya menggunakan spektrofotometer. Sedangkan untuk pengukuran blanko yaitu dengan penambahan Caulin clay sebanyak $9 \mathrm{ml}$ dan 
Optimasi Pembentukan Bioflok Dari Chaetoceros sp., Thalassiosira sp. dan Bakteri Probiotik Melalui Variasi Salinitas Secara In Vitro

(hlm. 140-151)

$\mathrm{CaCl}_{2}$ sebanyak $0,25 \mathrm{ml}$ tanpa sampel dan diukur menggunakan spektrofotometer. Menurut Kurane et.al. (1991), Aktivitas Flok dapat dihitung menggunakan persamaan:

$$
\text { Aktivitas Flok (F. Activity) }=\frac{\text { A - B }}{\text { A }} \times 100 \%
$$

Keterangan: A = Kerapatan Optis (OD) blanko

$$
\mathrm{B}=\text { Kerapatan Optis (OD) sampel }
$$

Pengukuran suhu menggunakan thermometer $\left({ }^{\circ} \mathrm{C}\right)$, dan pengukuran $\mathrm{pH}$ menggunakan $\mathrm{pH}$ meter yang dilakukan setiap hari. Sedangkan pengukuran intensitas cahaya yang menggunakan lux meter (lux) dan pengukuran laju aerasi dilakukan pada awal penelitian yaitu untuk mengetahui laju aerasi yang digunakan ( $\mathrm{ml} /$ menit).

\section{Analisis Data}

Analisis statistik terhadap data hasil penelitian dilakukan menggunakan program SPSS yaitu melakukan uji statistik analisis variansi (One-way ANOVA) untuk mengetahui derajat signifikansi perbedaan dari setiap perlakuan selama penelitian, sedangkan untuk mengetahui signifikansi perbedaan rata-rata dengan tingkat kepercayaan 95\% ( $\alpha: 0.05$ ) yang dilanjutkan dengan menggunakan uji Duncan.

\section{Hasil dan Pembahasan}

Penelitian tentang optimasi pembentukan bioflok dari Chaetoceros sp., Thalassiosira sp. dan bakteri probiotik melalui variasi salinitas secara In Vitro dengan parameter pengamatan biomassa (berat), volume flok, aktivitas flok, suhu, pH, laju aerasi dan intensitas cahaya. Berdasarkan hasil yang diperoleh, rata-rata hasil pengukuran biomassa flok yang dilakukan selama enam hari pengamatan dapat dilihat pada Tabel 1:

Tabel 1. Rata-rata biomassa flok $(\mathrm{g} / \mathrm{ml})$

\begin{tabular}{|c|c|c|}
\hline No. & Perlakuan & $\begin{array}{c}\text { Rata-Rata Biomassa } \\
\mathbf{( g / m l )}\end{array}$ \\
\hline 1 & S1 & $0,00380^{\mathrm{b}} \pm 0,00030$ \\
\hline 2 & S2 & $0,00546^{\mathrm{d}} \pm 0,00011$ \\
\hline 3 & S3 & $0,00463^{\mathrm{c}} \pm 0,00015$ \\
\hline 4 & S4 & $0,00373^{\mathrm{b}} \pm 0,00006$ \\
\hline 5 & S5 & $0,00216^{\mathrm{a}} \pm 0,00006$ \\
\hline
\end{tabular}

Keterangan: Huruf yang sama menunjukkan hasil yang "berbeda tidak nyata" berdasarkan uji Duncan dengan taraf kepercayaan $\alpha 0,05$. (S1 $=30$ ppt, S2 $=25$ ppt, S3 $=20$ ppt, $\mathrm{S} 4=15 \mathrm{ppt}, \mathrm{S} 5=5 \mathrm{ppt}$ ).

Tabel 1 menunjukkan rata-rata biomassa flok $(\mathrm{g} / \mathrm{ml})$. Hasil rata-rata biomasa flok pada perlakuan 30 ppt terhadap perlakuan 15 ppt menunjukkan hasil yang berbeda tidak nyata dan menunjukkan hasil berbeda nyata terhadap perlakuan 20 ppt dan $5 \mathrm{ppt}$, begitupun terhadap perlakuan 25 ppt menunjukkan hasil berbeda sangat nyata. Pada perlakuan 25 ppt menunjukkan hasil yang berbeda nyata terhadap perlakuan 20 ppt dan berbeda sangat nyata terhadap perlakuan $30 \mathrm{ppt}, 15 \mathrm{ppt}$, dan $5 \mathrm{ppt}$. Untuk perlakuan $20 \mathrm{ppt}$ menunjukkan hasil yang berbeda nyata terhadap perlakuan $30 \mathrm{ppt}, 15 \mathrm{ppt}$ dan juga $25 \mathrm{ppt}$. Selanjutnya untuk perlakuan 
15 ppt menunjukkan hasil yang berbeda nyata terhadap perlakuan 5 pt dan 20 ppt. Sedangkan untuk pada perlakuan 5 ppt menunjukkan hasil yang berbeda nyata terhadap perlakuan $30 \mathrm{ppt}$ dan 15 ppt serta menunjukkan hasil yang berbeda sangat nyata terhadap perlakuan 20 ppt dan 25 ppt. Rata-rata biomassa yang paling tinggi yakni pada perlakuan dengan salinitas $25 \mathrm{ppt}$ sebesar $0,00546 \mathrm{~g} / \mathrm{ml}$ dan rata-rata biomassa yang paling rendah yakni pada perlakuan dengan salinitas 5 ppt yaitu sebesar $0,00216 \mathrm{~g} / \mathrm{ml}$.

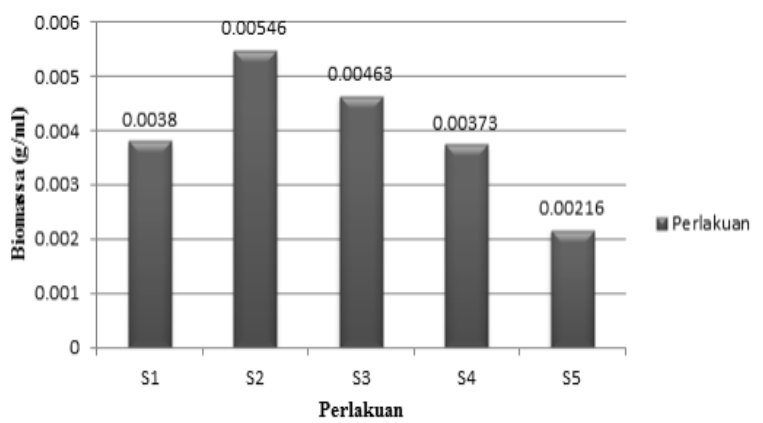

Gambar 1: Rata-rata biomassa flok $(\mathrm{g} / \mathrm{ml})$

(S1=30 ppt; S2=25 ppt; S3=20 ppt; S4=15 ppt; S5=5 ppt)

Rata-rata hasil pengukuran pada volume flok, yang dilakukan selama enam hari berturutturut, dapat dilihat pada Tabel 2 dan grafik pebentukan optimum bioflok dapat dilihat pada Gambar 2:

Tabel 2. Rata-rata volume flok (ml)

\begin{tabular}{|c|c|c|}
\hline No. & Perlakuan & Rata-Rata Volume (ml) \\
\hline 1 & S1 & $0,00483^{\mathrm{ab}} \pm 0,00085$ \\
\hline 2 & S2 & $0,00710^{\mathrm{c}} \pm 0,00122$ \\
\hline 3 & S3 & $0,00570^{\mathrm{bc}} \pm 0,00079$ \\
\hline 4 & S4 & $0,00467^{\mathrm{ab}} \pm 0,00076$ \\
\hline 5 & S5 & $0,00343^{\mathrm{a}} \pm 0,00071$ \\
\hline
\end{tabular}

Keterangan: $\mathrm{S} 1=30 \mathrm{ppt}, \mathrm{S} 2=25 \mathrm{ppt}, \mathrm{S} 3=20 \mathrm{ppt}, \mathrm{S} 4=15 \mathrm{ppt}, \mathrm{S} 5=5 \mathrm{ppt}$.

Hasil rata-rata volume flok pada perlakuan 30 ppt terhadap perlakuan 15 ppt menunjukkan hasil yang berbeda tidak nyata. Pada perlakuan 25 ppt menunjukkan hasil yang berbeda tidak nyata terhadap perlakuan $20 \mathrm{ppt}$, tetapi perlakuan $25 \mathrm{ppt}$ menunjukkan hasil berbeda nyata terhadap perlakuan $30 \mathrm{ppt}$, perlakuan $15 \mathrm{ppt}$ dan menunjukkan hasil yang sangat berbeda nyata terhadap perlakuan 5 ppt. Pada perlakuan 20 ppt menunjukkan hasil yang berbeda tidak nyata terhadap perlakuan $30 \mathrm{ppt}$, perlakuan $15 \mathrm{ppt}$ dan perlakuan $25 \mathrm{ppt}$, tetapi perlakuan $20 \mathrm{ppt}$ menunjukkan hasil yang berbeda nyata terhadap perlakuan 5 ppt. Pada perlakuan $15 \mathrm{ppt}$ menunjukkan hasil yang berbeda tidak nyata terhadap perlakuan $30 \mathrm{ppt}$, perlakuan $5 \mathrm{ppt}$ dan perlakuan $20 \mathrm{ppt}$, tetapi perlakuan 15 ppt menunjukkan hasil yang berbeda nyata terhadap perlakuan 25 ppt. Pada perlakuan 5 ppt menunjukkan hasil berbeda tidak nyata terhadap perlakuan 30 ppt dan perlakuan $15 \mathrm{ppt}$, tetapi perlakuan 5 ppt menunjukkan hasil yang berbeda nyata terhadap perlakuan 20 ppt dan menunjukkan hasil yang berbeda sangat nyata terhadap perlakuan 25 ppt. Rata-rata volume flok yang paling tinggi yaitu pada perlakuan dengan salinitas 25 ppt sebesar $0,0071 \mathrm{ml}$ dan rata-rata volume flok yang paling rendah yakni pada perlakuan dengan salinitas 5 pt yaitu sebesar $0,00343 \mathrm{ml}$. 
Optimasi Pembentukan Bioflok Dari Chaetoceros sp., Thalassiosira sp. dan Bakteri Probiotik Melalui Variasi Salinitas Secara In Vitro ISSN $1411-4720$

(hlm. 140-151)

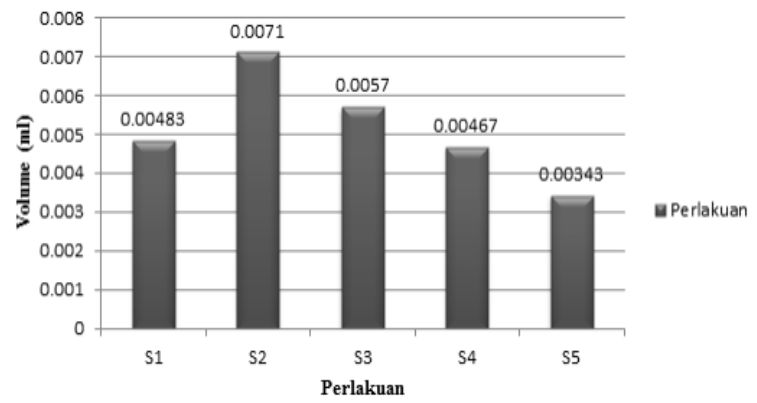

Gambar 2: Rata-rata volume flok (ml)

(S1=30 ppt; S2=25 ppt; S3=20 ppt; S4=15 ppt; S5=5 ppt).

Rata-rata hasil pengukuran pada aktivitas flok, yang dilakukan selama enam hari berturutturut, dapat dilihat pada Tabel 3 dan grafik pebentukan optimum bioflok dapat dilihat pada Gambar 3:

Tabel 3. Rata-rata aktivitas flok (\%)

\begin{tabular}{|c|c|c|}
\hline No. & Perlakuan & $\begin{array}{c}\text { Rata-Rata Aktivitas Flok } \\
\text { (\%) }\end{array}$ \\
\hline 1 & S1 & $62,4891^{\mathrm{a}} \pm 1,6569$ \\
\hline 2 & S2 & $77,0262^{\mathrm{a}} \pm 16,8499$ \\
\hline 3 & S3 & $68,3848^{\mathrm{a}} \pm 22,5178$ \\
\hline 4 & S4 & $60,0674^{\mathrm{a}} \pm 5,9488$ \\
\hline 5 & S5 & $58,6903^{\mathrm{a}} \pm 7,0184$ \\
\hline
\end{tabular}

Keterangan: $\mathrm{S} 1=30 \mathrm{ppt}, \mathrm{S} 2=25 \mathrm{ppt}, \mathrm{S} 3=20 \mathrm{ppt}, \mathrm{S} 4=15 \mathrm{ppt}, \mathrm{S} 5=5 \mathrm{ppt}$

Pada tabel 3 menunjukkan rata-rata aktivias flok pada saat pengukuran yang diperoleh dari semua perlakuan (S1, S2, S3, S4, dan S5) dengan variasi salinitas berturut-turut $30 \mathrm{ppt}, 25 \mathrm{ppt}$, 20 ppt, 15 ppt dan 5 ppt. Hasil rata-rata aktivitas flok menunjukkan tidak ada perbedaan terhadap semua perlakuan. Berdasarkan data tersebut rata-rata aktivitas flok yang paling tinggi adalah pada perlakuan dengan salinitas 25 ppt sebesar 77,02 \% dan rata-rata aktivitas yang paling rendah yakni pada perlakuan dengan salinitas 5 ppt sebesar $58,69 \%$.

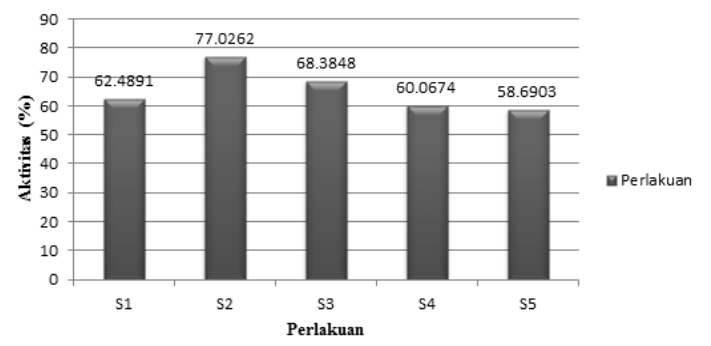

Gambar 3: Rata-rata aktivitas flok (\%) (s1=30 ppt; s2=25 ppt; s3=20 ppt; s4=15 ppt; s5=5 ppt)

Rata-rata hasil pengukuran beberapa parameter pendukung seperti suhu, $\mathrm{pH}$, intensitas cahaya, dan laju aerasi dapat dilihat pada Tabel 4: 
Tabel 4. Rata-rata parameter pendukung pembentukan bioflok

\begin{tabular}{|c|c|c|c|c|}
\hline \multirow{2}{*}{ Perlakuan } & \multicolumn{4}{|c|}{ Parameter Pendukung } \\
\cline { 2 - 5 } & Suhu $\mathbf{(}^{\circ} \mathbf{C}$ ) & $\mathbf{p H}$ & $\begin{array}{c}\text { Intensitas } \\
\text { Cahaya } \\
\text { (lux) }\end{array}$ & $\begin{array}{c}\text { Laju Aerasi } \\
\text { (ml/menit) }\end{array}$ \\
\hline S1 & 24 & $7,8-8,2$ & 1550 & 233 \\
\hline S2 & 24 & $7,4-8,1$ & 1550 & 233 \\
\hline S3 & 24 & $7,6-8,2$ & 1550 & 233 \\
\hline S4 & 24 & $7,3-8,2$ & 1550 & 233 \\
\hline S5 & 24 & $7,2-8,1$ & 1550 & 233 \\
\hline
\end{tabular}

Keterangan: $\mathrm{S} 1=30 \mathrm{ppt}, \mathrm{S} 2=25 \mathrm{ppt}, \mathrm{S} 3=20 \mathrm{ppt}, \mathrm{S} 4=15 \mathrm{ppt}, \mathrm{S} 5=5 \mathrm{ppt}$

Hasil rata-rata pengukuran suhu selama pengamatan yang telah dilakukan selama enam hari berturut-turut diperoleh data pada kelima perlakuan atau semua perlakuan yaitu $24^{\circ} \mathrm{C}$. Hasil rata-rata pengukuran $\mathrm{pH}$ selama pengamatan diperoleh data yaitu pada perlakuan $30 \mathrm{ppt}$, perlakuan $25 \mathrm{ppt}$, perlakuan $20 \mathrm{ppt}$, perlakuan $15 \mathrm{ppt}$, dan pada perlakuan 5 ppt yang dtunjukkan pada tabel 4, berkisar antara 7,8 hingga 8,2. Hasil pengukuran intensitas cahaya selama pengamatan pada Tabel 4 menunjukkan hasi sebesar 1550 lux pada perlakuan $30 \mathrm{ppt}$, perlakuan $25 \mathrm{ppt}$, perlakuan $20 \mathrm{ppt}$, perlakuan $15 \mathrm{ppt}$, dan pada perlakuan $5 \mathrm{ppt}$. Hasil pengukuran laju aerasi (ml/menit) selama pengamatan yang ditunjukkan pada Tabel 3 yakni $233 \mathrm{ml} /$ menit pada perlakuan $30 \mathrm{ppt}$, perlakuan $25 \mathrm{ppt}$, perlakuan $20 \mathrm{ppt}$, perlakuan $15 \mathrm{ppt}$, dan pada perlakuan $5 \mathrm{ppt}$.

\section{Pembahasan}

Optimasi pembentukan bioflok yang dari Chaetoceros sp., Thalassiosira sp. dan bakteri probiotik melalui variasi salinitas secara in vitro, dimana sebagai tahap awal proses pembentukan bioflok yang teridiri dari mikroorganisme pembentuk flok adalah bakteri probiotik juga fitoplankton yang terdiri dari Chaetoceros sp., Thalassiosira sp. yang dikultivasi pada medium Walne dengan berbagai variasi salinitas yang berbeda, yaitu terbagi atas lima varisasi atau lima perlakuan yaitu perlakuan pertama : S1 (30 ppt), perlakuan kedua : S2 (25 ppt), perlakuan ke tiga : S3 (20 ppt), perlakuan keempat : S4 (15 ppt), perlakuan kelima : S5 (5 ppt). Menurut Widianingsih et al., (2008), media Walne merupakan media kultur yang baik bagi mikroalga atau fitoplankton, karena media Walne memiliki komposisi nutrien yang lengkap.

Pembentukan bioflok dapat diketahui berdasarkan biomassa yang dinyatakan dalam berat kering. Berdasarkan pada data hasil uji statistik yang diperoleh terhadap pengukuran biomasa flok, telah terlihat bahwa perlakuan dengan salinitas 25 ppt (S2) memiliki biomassa yang paling tinggi. Hal ini terjadi dikarenakan mikroorganisme pembentuk flok seperti fitoplankton aktif atau memiliki pertumbuhan yang baik pada salinitas optimum antara 25-35 ppt. Sylvester et al., (2002), berpendapat bahwa salinitas merupakan konsentrasi garam yang terlarut dalam satuan air. Salinitas merupakan salah satu faktor pembatas bagi pertumbuhan dan perkembangan fitoplankton. Fluktuasi salinitas secara langsung menyebabkan perubahan tekanan osmosis di dalam sel fitoplankton. Umumnya fitoplankton air laut hidup normal pada salinitas 25-35 \%o.

Salinitas rendah berkontribusi pada penurunan kinerja osmoregulasi dan peningkatan replikasi WSSV atau virus penyebab penyakit, sehingga tingkat kematian mikroorganisme pembentuk flok yaitu fitoplankton lebih tinggi (Mukhammad et.al., 2015). Hal ini dapat dilihat berdasarkan pada hasil pengamatan yang telah terlihat bahwa perlakuan dengan salinitas $5 \mathrm{ppt}$ (S5) yang merupakan perlakuan dengan tingkat salinitas yang rendah dan memiliki biomassa paling rendah yaitu hanya sebesar $0,00216 \mathrm{~g} / \mathrm{ml}$. begitupun terlihat pada perlakuan dengan 
Optimasi Pembentukan Bioflok Dari Chaetoceros sp., Thalassiosira sp. dan Bakteri Probiotik Melalui Variasi Salinitas Secara In Vitro

(hlm. 140-151)

salinitas 30 ppt (S1) yang merupakan perlakuan dengan salinitas tertinggi memiliki biomassa yang cukup rendah yaitu sebesar $0,00380 \mathrm{gr} / \mathrm{ml}$. Hal ini terjadi karena pada aktifitas sel maupun proses metabolisme sel mikoorganisme tidak dapat bekerja maksimal sehingga juga menyebabkan tingkat kematian mikroorganisme pembentuk flok lebih tinggi. Ini sesuai dengan yang dilaporkan oleh Sylvester et., al (2002), bahwa salinitas yang terlampau tingggi atau rendah dapat menyebabkan tekanan osmosis di dalam sel menjadi lebih rendah, sehingga aktifitas sel terganggu. Hal ini mempengaruhi protoplasma sel dan menurunkan kegiatan enzim di dalam sel.

Pembentukan bioflok dapat juga diketahui berdasarkan parameter volume flok. Suprapto dan Samtafsir (2013), menyatakan bahwa volume flok merupakan salah satu cara untuk melihat kelimpahan organisme pembentuk bioflok. Mikroba penyusun bioflok terdiri dari bacteria, protozoa, dan mikroalga (fitoplankton atau zooplankton) (Gunarto dan Suwoyo, 2011). Hasil pengamatan volume flok memperlihatkan bahwa perlakuan dengan salinitas 25 ppt (S2) memiliki nilai rata-rata tertinggi di bandingkan dengan perlakuan lainnya yang menunjukkan perbedaan yang sangat nyata dengan perlakuan lainnya yaitu sebesar 0,00710 $\mathrm{ml}$. Hal ini disebabkan karena pada salinitas tersebut merupakan salinitas yang baik untuk perrtumbuhan mikroorganisme pembentuk flok, yaitu dominansi fitoplankton air laut yang hidup normal pada salinitas 25-35 \%o (Sylvester et al., 2002), yang kemudian diikuti oleh perkembangan pertumbuhan bakteri heterotrof yang berasal dari probiotik yang digunakan

Menurut Gunarto et al., (2012), Dengan variasinya jenis probiotik yang digunakan, maka kemungkinan terjadi bioflokulasi yang terdiri dari kombinasi antara bakteri dan fitoplankton yang sangat baik. Adapun pada perlakuan dalam upaya pembentukan flok yang dilakukan kurang lebih selama enam hari berturut-turut dilakukan kombinasi antara fitoplankton Chaetoceros sp., Thalassiosira sp. dengan bakteri probiotik seperti Rhodobacter sp. dan Rhodococcus sp.

Bioflok dapat terbetuk karena adanya aktifitas mikrooganisme pembentuk flok dalam upayanya untuk saling mengikat membetuk (agregat). Adanya aktivitas flok ditandai dengan sisitem flokulasi. Berdasarkan pada data yang diperoleh walaupun secara statistik menunjukkan tidak ada perbedaan (rata-rata) antara semua perlakuan (tidak signifikan), tetapi secara numerik berdasarkan pada hasil pengamatan aktivitas flok, masih terlihat rata-rata aktivitas flok yang paling tinggi yang ditunjukkan oleh perlakuan dengan salinitas 25 ppt (S2) yaitu sebesar 77,0262 \%. Sedangkan rata-rata aktivitas flok yang paling rendah ditunjukkan oleh perlakuan dengan salinitas 5 ppt (S5) yaitu sebesar 58,6903 \%. Begitupun data yang ditujukkan pada perlakuan dengan salinitas tertinggi yaitu salinitas 30 ppt (S1) hanya memperoleh nilai sebesar 62,4891 \%. Hal ini terjadi dikarenakan mikroorganisme pembentuk flok berkembang baik dalam media kultur optimal sehingga proses kegiatan enzim maupun aktivitas metabolisme sel dapat berjalan dengan baik yang nantinya dapat meningkatkan laju pertumbuhan mikroorganisme pembentuk flok, serta untuk meningkatkan aktivitas saling mengikat membetuk (agregat), baik fitoplankton maupun bakteri. Sylvester et.,al (2002), mengemukakan bahwa, salinitas yang terlampau tingggi atau rendah dapat menyebabkan tekanan osmosis di dalam sel menjadi lebih rendah, sehingga aktifitas sel terganggu. Tingginya aktivitas mikroorganisme pembentuk flok dalam membentuk suatu partikel suspensi dapat tergantung pada pengaruh tingkat kekuatan ion terhadap agregasi bakteri. Bakteri yang teragregasi akan membentuk partikel yang lebih besar dan memiliki kemampuan untuk mengendap apabila dilakukan proses sedimentasi (Suazo 2006).

Selain salinitas dan kandungan nutrient, pembentukan bioflok juga dipengaruhi oleh kondisi lingkungan kultur lain seperti suhu, $\mathrm{pH}$, intensitas cahaya dan laju aerasi. Hasil pengamatan dan pengukuran suhu selama penelitian pada tiap perlakuan pada tabel 4.4 menunjukkan suhu yang bersifat stabil yaitu sebesar $24^{\circ} \mathrm{C}$. Suhu merupakan faktor lingkungan yang sangat penting yang mempengaruhi aktivitas organisme. Suhu terutama mempengaruhi aktivitas enzim (Ali, 2005). 
Hasil pengamatan dan pengukuran $\mathrm{pH}$ selama penelitian pada tiap perlakuan menunjukkan kisaran pH sebesar 7,2 - 8,2 pada tiap perlakuan. Hal ini menunjukkan kisaran $\mathrm{pH}$ yang masih termasuk dalam kisaran $\mathrm{pH}$ optimum untuk mendukung pembentukan bioflok oleh mikroorganisme pembentuk flok. Kondisi pH akan berpengaruh terhadap kestabilan flok. Penambahan bahan yang dapat nenaikkan atau menurunkan $\mathrm{pH}$ dapat membantu kestabilan flok, pH akan berkaitan dengan nilai alkalinitas dan konduktifitas (Laksono, 2013).

Hasil pengamatan intensitas cahaya selama penelitian menunjukkan 1550 lux. Hal ini menunjukkan kisaran yang masih termasuk dalam kisaran intensitas cahaya optimum untuk mendukung pembentukan bioflok oleh mikroorganisme pembentuk flok. Saat keadaan cahaya matahari kurang memadai, cahaya matahari dapat diganti dengan sinar lampu TL dengan intensitas cahaya antara 5000-10.000 lux. Menurut Suryati (2002), menyatakan bahwa intensitas cahaya yang optimal untuk pertumbuhan fitoplankton yang dikombinasikan dengan bakteri heterotrof dalam membentuk flok adalah berkisar antara 1500-3000 lux dan tidak melebihi 4000 lux.

Hasil pengukuran laju aerasi yang digunakan selama penelitian yaitu $233 \mathrm{ml} /$ menit. Proses pengadukan (agitasi) merupakan salah satu proses penting untuk mengoptimalkan pembentukan bioflok. Salah satu cara pengadukan yang efektif dan mudah dilakukan adalah dengan aerasi. Aerasi berfungsi untuk menambah susplai oksigen dalam air, dimana oksigen sangat diperlukan oleh mikroorganisme untuk mengurai bahan organik. Pengadukan berfungsi untuk mencegah bahan organik dan flok mengendap di dasar (Laksono, 2013).

\section{Kesimpulan}

Berdasarkan penelitian yang telah dilakukan, maka dapat disimpulkan bahwa tingkat salinitas optimum yang digunakan pada medium Walne dalam mengoptimalkan pembentukan bioflok dari Chaetoceros sp., Thalassiosira sp. dan bakteri probiotik adalah perlakuan S2 sebesar 25 ppt dengan indikator biomassa flok $0.00546 \mathrm{~g} / \mathrm{ml}$, volume flok sebesar $0.0071 \mathrm{ml}$, dan aktivitas flok sebesar $77.0262 \%$.

\section{Refenrensi}

Ali, Alimuddin. (2005). Mikrobiologi Dasar Jilid I. Badan Penerbit UNM, Makassar.

Avnimelech, Y. (2007). Feeding with Microbial Flocs by Tilapia in Minimal Discharge Bio-flocs Technology Ponds. Aquaculture. 264, 140-147.

Coutteau, E. (1998). Algal Production. University of Gent, Belgium.

Erniati \& Hairina. (2012). Pemberian Mikroalga yang Berbeda Terhadap Pertumbuhan Artemia salina. Berkala Perikanan Terubuk. 40 (2).

Febrianti, D., Widiani, I., \& Suryani, A.A. (2010). Pendekatan Teknologi Bioflok (Bft) Berbasis Probiotik Bacillus Subtilis Pada Tambak Udang Vaname Litopanaeus vanamei. Program Kreativitas Mahasiswa. Jurusan Budidaya Perairan. Institut Pertanian Bogor.

Gunarto \& Suwoyo, H.S. (2011). Produksi Bioflok dan Nilai Nutrisinya dalam Skala Laboratorium. Prosiding Forum Inovasi Teknologi Akuakultur. Balai Riset Perikanan Budidaya Air Payau.

Gunarto, Suwoyo, H.S., Syafa'at, M.N. (2012). Budidaya Udang Vaname, Litopenaeus Vannamei Pola Intensif dengan Penambahan Molase. Prosiding Indoaqua - Forum Inovasi Teknologi Akuakultur. Balai Penelitian dan Pengembangan Budidaya Air Payau. 
Optimasi Pembentukan Bioflok Dari Chaetoceros sp., Thalassiosira sp. dan ISSN $1411-4720$

Bakteri Probiotik Melalui Variasi Salinitas Secara In Vitro

(hlm. 140-151)

Haliman \& Adijaya. (2005). Pembudidayaan dan Prospek Pasar Udang Putih yang Tahan Penyakit. Penebar Swadaya, Jakarta.

Hargreaves, J.A. (2006). Photosynthetic Suspended-Growth Systems In Aquaculture. Aquaculture Engineering 34, 344-363.

Kurane, R. Takeda, K., Tomo, S. (1991). Screening and Characteristic Of Microbial Flocculants. Neuroscience 29.

Kurniawati, Rizki, A. (2006). Peningkatan Produktivitas Kultur dalam Chaetoceros amami Melalui Optimasi Rasio N:P:Si. Skripsi. Program Studi Bioteknologi Sekolah Ilmu dan Teknologi Hayati, Insitut Tekninologi Bandung.

Laksono. M. (2013). Pengenalan Bioflok untuk Akuakultur (Aquacuture). Diakses pada tanggal 10 september 2017. https://PerikananBojongsari. Artikelbio.com/Pengenalan Bioflok untuk Akuakultur (Aquacuture)

Mukhammad A. A., Sri W., \& Yuni K. (2015). Dampak Stres Salinitas Terhadap Prevalensi White Spot Syndrome Virus (WSSV) dan Survival Rate Udang Vannamei (Litopenaeus vannamei) pada Kondisi Terkontrol. Research Journal Of Life Science. 2 (1), 34-47

Pantjara, B. (2008). Efektivitas sumber C terhadap dekomposisi bahan organik limbah tambak udang intensif. Prosiding Seminar Nasional IV Universitas Hangtuah, Surabaya.

Stickney, R. R., (2005). Aquaculture: An Introductory Text. CABI Publishing. USA.256p.

Suazo, F.J.C. (2006). Effect of reactor feeding pattern on performance of an activated sludge SBR [Tesis]. San Fransisco, Virginia Polytechnic Institute and State University.

Suprapto \& Samtafsir LS. (2013). Biofok 165 Rahasia Sukses Teknologi Budidaya Lele.

Suryati. (2002). Pemanfaatan Limbah Cair Pabrik Gula (LCPG) untuk Pertumbuhan Spirulina sp.. Skripsi. Fakultas Perikanan Universitas Brawijaya. Malang.

Sylvester, B., D.D. Nelvy, dan Sudjiharno. (2002). Persyaratan Budidaya Fitoplankton. Budidaya Fitoplankton dan Zooplankton. (Prosiding) Proyek Pengembangan Perekayasaan Tekologi Balai Budidaya Laut Lampung Tahun. 24-36.

Tripathy, T., De Ranjan, B. (2006). Flocculation: A New Way To Treat The Waste Water. Journal of Physical Sciences. 10, 93-27.

Triswanto, Y. (2011). Kutivasi Diatom Penghasil Biofuel Jenis Scletonema costatum, Thalassiosira sp., dan Chaetoceros gracilis pada Sistem Indoor dan Outdoor. Skripsi. Program Ilmu dan Teknologi Kelautan: Insitut Pertanian Bogor.

Widianingsih, A., Ridho, R., Hartati, \& Harmoko. 2008. Kandungan Nutrisi Spirulina platensis yang Dikultur pada Media yang Berbeda. Ilmu Kelautan. 13 (3),167. 
ISSN $1411-4720$

Optimasi Pembentukan Bioflok Dari Chaetoceros sp., Thalassiosira sp. dan

Bakteri Probiotik Melalui Variasi Salinitas Secara In Vitro

(hlm. 140-151)

\section{Suciati Nurdin}

S.Si., Prodi Biologi Fakultas Matematika dan Ilmu Pengetahuan Alam

Universitas Negeri Makassar, Indonesia.

E-mail: suciatinurdin@yahoo.com 